\title{
Evidence and Its Proof. Designing a Test of Evidence
}

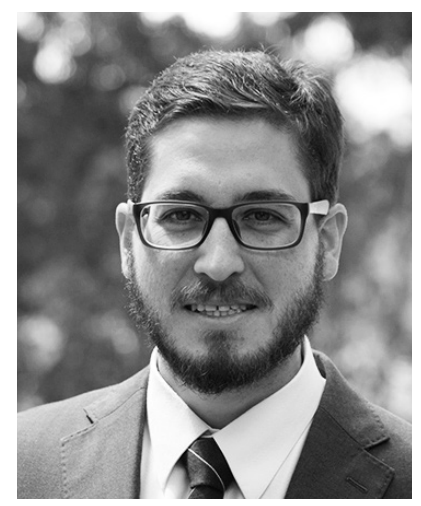

\section{Juan Carlos Riofrío}

Professor of Fundamental Theory of

Law at Los Hemisferios University

(Quito, Ecuador).

$\triangle$ juancarlosr@uhemisferios.edu.ec

http://orcid.org/oooo-0003-4461-1025

Key words: methodology, legal studies, philosophy of law, law epistemology, evident knowledge, scientific knowledge

https://doi.org/10.32082/fp.v3i53.219

\section{Introduction}

Nowadays knowledge and truth are under attack, and, as a consequence, we are losing the notion of evidence as "obvious". Probably that's why George Orwell ${ }^{1}$ considered that one of the principal duties of today's world is to recover what is obvious. In these days, when the manipulation of language for political ends grows strongly, when "war is peace», «freedom is slavery», «ignorance is strength», we must rediscover the basic principles of our reason. «We have now sunk to a depth at which restatement of the obvious is the first duty of intelligent men».

Understanding how human knowledge functions has always been complex. In general, it is accepted that we can understand reality from various sources: from immediate evidence (evidence from the senses or intellect), from more or less complex reasoning, as well as faith in some authority.

1 Orwell, G., Facing Unpleasant Facts: Narrative Essays. Boston: Mariner Books 2009.
From all of these sources evidence plays a crucial role, because all knowledge is built on it: analyzing what is evident we draw conclusions, and the new ideas or hypotheses are confronted with the most obvious to confirm its truth. Knowledge is constructed in layers, atop the floor of evidence. ${ }^{2}$

But evidence is not an exclusive subject in philosophy; it also interests the judge, the lawyer and those who continually raise its argument about the pillar of

2 The levels of understanding have been studied from diverse perspectives. Already in Aristotle's Organon, founder of logic, it appears that the syllogisms form from the senses, the senses from the concepts, and the concepts from the perception of the senses. From the levels of knowing, cf. Maritain, J., Los grados del saber. Alfredo Frossard (trad.). Buenos Aires: Desclée de Brouwer 1947, Maritain, J., El orden de los conceptos. Gilberte Motteau de Buedo (trad.). Buenos Aires: Club de Lectores 1967; Cruz Cruz, J., Intelecto y razón. Las coordenadas del pensamiento clásico. Pamplona: Eunsa 1982, 45-67. 
what is evident: Should what is evident be proven when everyone attacks it? And, more difficult still: How to test that the obvious is evident, when it suffers from a general threat?

In an age like the one in which we live, we have lost the sense of what is real and what is evident. Nowadays it becomes imperious to know if there is any kind of proof which defines what things are evident. In order to find it we will proceed in the following manner: first we will review how evidence has been understood in classic philosophy, besides seeing some current relevant contributions (Chapter II); then we will get into it in a systematic method of understanding what is evident, from its types, characteristics and functions (Chapter III), with this background to be able to postulate a test about whether something is evident, confirming if it meets the characteristics of what is evident.

\section{The Notion of Evidence in Philosophy}

It is interesting to see how the first thing discovered in history is that evidence is related to the senses. A footprint has stayed in the language: the word anchors its origin in the Latin term evidentia, which comes from videre, vision. In this sense, evidence is what falls under our eyes. Something similar happened in ancient philosophy with Epicurus. He considered all knowledge to be based in sensory perception: if something is perceived by the senses, it is evident, it is always true. ${ }^{3}$

Aristotle went beyond that concept of evidence as a simple passive perception of the senses. He observed that, although all superior animals could have sensory experiences of things, only human beings had to conceptualize them and penetrate more and more into their reality. This certain understanding that the intellect obtains things when it sees them, it makes it in an innate and necessary way (it is not something acquired, as can be the habit of science, of which he speaks in Ethics IV). For Aristotle the evidence it not merely the passive perception of reality, but a gradual

3 Cf. Letter to Diogenes Laertius, X, 52.

4 Cf. Aristóteles, Metafísica (trad. de V. García Yebra). Madrid: Gredos 2012, 449, b; same, About the Memory, 452, a; same, Física. Trad. de G. Rodríguez de Echandía. Madrid: Gredos 1995, I, c. 1. process of discoveries, a knowledge that "determines and divides" better and better the "undetermined and undefined": it begins with what is most evident for us, in order to end with what is truer and more evident in nature. ${ }^{5}$

Thomas Aquinas will later deepen the distinction of evidence quad nos and quad se already suggested by Aristotle. ${ }^{6}$ Neither of the two understood evidence in purely logical or formal terms, like many schools of thought tend to understand today. ${ }^{7}$ His theory of knowledge proves to be much richer. In philosophical realism, the senses (sight, sound, etc.) provide correct data of what reality is; they do not lie to us, unless they are atrophied. When the sensitive species (or the Aristotelian phantom) formed by the inferior powers is captured by intelligence, it immediately knows and abstracts data from reality; the intelligence with its light, through "study," "determination" and "division" will end up forming concepts, judgements and reasoning. That first immediate acquisition of reality, devoid of structured reasoning, is the first evidence captured by the intellect. Then the intellect is aware of other obvious truths (such as $2+2=4$ or that "the total is greater than or equal to the part") when it compares and relates the previously assimilated knowledge.

Scholastic tradition considered that there existed some "primary principles of practical reason," known as immediately and clearly, that could never be broken or repealed. These moral principles would be the most nuclear of natural law. But in addition to those, there would be another part of natural law (formed by deductions or specifications of those principles) that could vary with time and with changing circumstances. ${ }^{8}$ In this way, natural law would be comprised

5 Cf. Morán y Castellanos, J., Evidencia de la naturaleza en Aristóteles. Tópicos: revista de Filosofía, 4(6), 1994, 71-87.

6 Cf. Tomas de Aquino, Suma Teológica. París-Italia. Traducción al castellano de BAC. Suma Teológica de Santo Tomás de Aquino, 4 ed. Madrid: BAC 2001.I, q. 2, sol.

7 Meaning that "formal evidence" is merely logic. According to it, it is clear that "if all elephants have wings and all the winged beings fly, then all elephants fly."

8 Cf. Tomas de Aquino, Suma Teológica. París-Italia. Traducción al castellano de BAC. Suma Teológica de Santo Tomás de Aquino, $4^{\text {a }}$ ed. Madrid: BAC 2001.I-II, q. a. 5, sol. 
of some small immutable principles and by enormous variable content.

In the last decades the New School of Natural Law has reopened the debate on which all its out evidence of these primary principles. It is a cardinal question within the School, on which all its argumentative structure is built. From the beginning, Grisez ${ }^{9}$ proposed the existence of basic human values and principles that would be self-evident, a doctrine that would be followed and developed by Finnis. ${ }^{10}$ Authors of this school will point out that there are seven basic goods (life, knowledge, friendship and sociability, play, aesthetic experience, practical reasonableness and religion), the pre-moral principles which express an acceptable character of the basic human goods and the evident moral principles which express the proper connection among certain types of human actions and the basic goods. ${ }^{11}$ Such a justification in evidence will awaken the satisfaction or rejection of many, and a series of opposing writings. ${ }^{12}$

9 Grisez, G., The First Principles of Practical Reasons: A Commentary on the Suma Theologiae, 1-2, Question 94, Article 2. Natural Law Forum, 44(4), 1965, p. 44.

10 Finnis, J., Ley Natural y Derechos naturales. Cristóbal S. Orrego (trad.). Buenos Aires: Ed. Abeledo-Perrot 2000, p. $34-35,86$.

11 See especially Finnis, J., Natural Law. Aldershot: Dartmouth 1991, xi.

12 Porter, J., Basic Goods and the Human Good in Recent Catholic Moral Theology, The Thomist, 57(1), 1993, p. 27 will say that the justification in the evidence of basic goods is arbitrary and false. Bradley, G.V. and George, R., The New Natural Law Theory: A Reply to Jean Porter. The American Journal of Jurisprudence, 39, 1994, p. 303-315 will emerge, pointing out that the school faithfully follows the Thomistic idea of evident principles, also pointing out that is not so clear that the new school speaks of the self-evidence of basic goods. Sayers, M., Knowledge as a Self-Evident Good in Finnis and Aquinas: When is the Immediately Obvious Not So Immediate. Australian Journal of Legal Philosophy, 23, 1998, p. 92-101 also doubts the fidelity of the Thomistic principles of the New School. In favor of O'Connell, I., Self-Evidence in Finnis' Natural Law. Theory: A Reply to Sayers. Australian Journal of Legal Philosophy, 25, 2000, p. 111-119. Cf. Orrego S., C., John Finnis. Controversias
Finnis, Grisez and Boyle ${ }^{13}$ point out that what is self-evident cannot be verified by experience, nor derived from any previous knowledge, nor inferred from any basic truth through a middle ground. Immediately they point out that the first principles are evident per se nota, known only through the knowledge of the meanings of the terms, and clarify that "This does not mean that they are mere linguistic clarifications, nor that they are intuitions-insights unrelated to data. Rather, it means that these truths are known (nota) without any middle term (per se), by understanding what is signified by their terms." Then when speaking specifically about the practical principles, they point out that they are not intuitions without contents, but their data come from the object to which natural human dispositions tend, that motivate human behavior and guide actions. ${ }^{14}$ Those goods to which humans primarily tend, which cannot be "reduced" to another good (it is to say, that they are not a means to an end), they are considered "evident": "as the basic good are reasons with no further reasons". ${ }^{15}$

Finally, in order to find the complete list of evident principles of practical reason, they create a method that calls for: (i) analyzing actions and their most profound reasons; (ii) theoretical studies about human beings which detect with precision natural inclinations; (iii) anthropological studies which examine motives and purposes of the behavior of all cultures; it would look like everyone seeks to subsist, to know, to live in harmony, etc.; (iv) to take some candidates from the list of principles in dialectic form, it is to say, comparing the basic goods with those that supposedly are. ${ }^{16}$ It is about a way to discover a list of evident contents, not to test its evidence.

In the last century, Husserl and phenomenology made some contributions to the understanding of what is evident, as we will see in the following chapter.

contemporáneas sobre la teoría de la ley natural. Acta Philosophica, 10(1), 2001, p. 73-92.

13 Finnis, J., Grisez, G. and Boyle, J., Practical Principles, Moral Truth, and Ultimate Ends. American Journal of Jurisprudence, 32, 1987, p. 106.

14 Ibid., p. 108.

15 Ibid., p. 110.

16 Ibid., p. 113. 


\section{Understanding What is Evident}

\subsection{Notion of What is Evident}

Evident is a clear understanding that captures in an immediate and direct way what things are.

In general, we can say that evident is a clear understanding that captures in an immediate and direct way what things are. We will attempt to explain it.

The most palpable in this case is that evidence has to be seen with clarity. In addition to what is attested to by philosophers, ${ }^{17}$ perseverance of this also exists in the language. Merriam Webster's Dictionary defines evident as "clear to the vision or understanding". ${ }^{18} \mathrm{~A}$ similar notion appears in French, German and other languages. Also, the Greek term évá $\rho \gamma \varepsilon ı a$ (enargeia) means the clarity of what is luminous or translucent. And we have already seen that the Latin term eviden- in phenomenology, things in reality shine, manifest, show themselves to the intellect. When the intellect illuminates the phantom and captures the glow of things, evidence appears. Evidence is not the thing, nor the intellect, nor the brightness, nor the truth, but "the presence of a reality as unequivocal and clearly given to intelligence". ${ }^{19}$ Such presence is knowledge.

But the obvious is not any type of knowledge but an immediate and direct knowledge ${ }^{20}$ of vision, where no new operation or intellectual inspection is necessary in order to understand. Here the intellect sees and automatically captures the truth. This means that evidence is patent in itself. ${ }^{21}$ It is often said that it is "self-justifying" or self-evident, which applies more to intellectual evidence (which certainly self-justifies, because the predicate is included in the subject), and applies less to sensory evidence which comes through

\section{Evident is a clear understanding that captures} in an immediate and direct way what things are.

tia comes from videre, vision. Therefore, we conclude that evident is that which we see in a clear manner.

Truth and clarity are two key elements for understanding evidence. We remember that truth was that adaptation between the thing and the intellect (truth of correspondence). Both in classical philosophy, like

17 Descartes associates evidence with "clarity and distinction" (Descartes, R., Meditationes de prima philosophia. Hay traducción castellana de Mígues, J.A. Meditaciones Metafísicas. Santiago de Chile: Arcis 2004, discurso VI). Leibniz (Leibniz, G., Nouveaux essais sur l'entendement humain. París 1765, IV, cap. 11\$10) conceives evidence as a luminous certainty, which results from the combination of ideas. D'Alambert, J., L'Encyclopédie ou Dictionnaire raisonné des sciences, des arts et des métiers 1739, p.127, for his part, he calls evidence the clarity of a sentence which is sufficient to understand its truth.

18 In Spanish - as well as other romance languages - evidencia differs absolutely from prueba (proof). The Spanish Royal Academy (Real Academia Española, Diccionario de la Lengua Española. Madrid 2016) defines evidence as the "clear certainty and states what cannot be doubted." the simple apprehension of the senses (that in ownership does not self-justify but is patent). In any case, the obvious things do not require further justification, to such a point that the most obvious becomes unprovable.

For us there are things which are more obvious than others, from where a certain analogy of the concept emerges. In the same place where Aquinas studies evidence, he points out that "that this proposition, 'God exists,' of itself is self-evident, for the predicate is the same as the subject, because God is His own existence" but, as "because we do not know the essence of God, the proposition is not self-evident to us". ${ }^{22}$ From the

19 Llano, A., Gnoseología. Pamplona: Eunsa 1991, p. 52.

20 Corazón González, R., Filosofía del conocimiento. Pamplona: Eunsa 2002, p. 161-162.

21 That is why it is understood that Kant conceives it as "an apodictic certainty."

22 Tomas de Aquino, Suma Teológica. París-Italia. Traducción al castellano de BAC. Suma Teológica de Santo Tomás de Aquino, 4a ed. Madrid: BAC 2001, I, q. 2, a. 1, sol. 
passage we infer that the analogatum princeps must be the quad se evidence (in itself), and the derived analogies will give the quad nos evidence (in that which is most evident for us). One of these derivatives will justly be the English evidence (which fundamentally means "proof"), ${ }^{23}$ which can be justly called "evidence."

The most obvious things are the first that the intellect assimilates. When a child opens his/her eyes to the world he/she captures a series of sensations that he/she does not know yet how to interpret. Then arises a question: What is it? It captures that there is something, that "something is." The being is the first that captures what is evident. The determinations of that being will later be captured: that something is good or bad, that the hand is mine, etc. The perception of time also appears in a natural way, from movement, the sense of causality, together with the first metaphysical and logical principles (e.g. the principle of no contradiction, the principle of the identity, the principle of the excluded third party, etc.). From these first ideas all subsequent knowledge will assemble. Without evidence there is no possibility of any knowledge. ${ }^{24}$

The obvious often opposes discursive knowledge, which certainly is less obvious. Discursive knowledge is that which is obtained based on reasons which are more or less articulated, which goes from what is known to the unknown, from the sure to the doubtful or hypothetical, from what is clear to the initial obscure or unknown conclusions. Evidence is an intellectual understanding of vision, while discourse implies a more exhausting inspection. The argument presupposes discourse, discourse presupposes intellectual evidence, and intellectual evidence presupposes sensitive evidence.

23 Concerning the English notion of "evidence" and its relation to intellectual evidence, see Sokolowski, R., Introduction to Phenomenology. Cambridge-New York: Cambridge University Press 2008, p. 159-162. Perhaps the concept of analogy could have been explored more.

24 Aristotle pointed out that "the most knowable are the first principles and causes, since by them and from them they come to know other things, and not of them through what is subordinated to them" (Aristóteles, Metafísica (trad. de V. García Yebra). Madrid: Gredos 2012., I, 2, 982b 2-4).

\subsection{Types of Evidence}

Classifications can be infinite. Here we will only use four criteria:

a. According to corporality, there is evidence of the simple apprehension of the senses and intellectual evidence. At the same time, phenomenology distinguishes evidence of disclosure (or direct capture of the object) and the evidence that captures the truth of correctness (or intellectual evidence), giving primacy to the evidence that is obtained from direct experience of the things. ${ }^{25}$

b. According to point of view, there is quad se and quad nos evidence. They are self-evident things that the knowledge obtained by simple sensorial apprehension and propositions which: (i) result from intuitive knowledge; or (ii) they have a predicate that is included in the subject necessarily. ${ }^{26}$ In this case it suffices to know the terms of the proposition in order to immediately notice that the predicate suits the subject. But it can follow that what is evident for one citizen is not evident for another. For a mathematician the most elementary theorems will be evident, like those of Tales, Bayes, or Pythagoras, while they will prove strange to most musicians. ${ }^{27}$ The quad nos evidence only reaches those who know all the terms

25 Cf. Sokolowski, R., Introduction to Phenomenology. Cambridge-New York: Cambridge University Press 2008, p. $158-162$.

26 In this sense it is pointed out that "the intellect is always right as regards first principles; since it is not deceived about them for the same reason that it is not deceived about what a thing is. For self-known principles are such as are known as soon as the terms are understood, from the fact that the predicate is contained in the definition of the subject" (Tomas de Aquino, Suma Teológica. París-Italia. Traducción al castellano de BAC. Suma Teológica de Santo Tomás de Aquino, $4^{\text {a }}$ ed. Madrid: BAC 2001, I, q. 17, a. 3, ad 2).

27 Aquinas explained in a more abstract and general way: "experience shows that some understand more profoundly than do others; as one who carries a conclusion to its first principles and ultimate causes understands it better than the one who reduces it only to its proximate causes" (Tomas de Aquino, Suma Teológica. París-Italia. Traducción al castellano de BAC. Suma Teológica de Santo Tomás de Aquino, $4^{\text {a }}$ ed. Madrid: BAC 2001, I, q. 85, a. 7, sed). 
which constitute the subject and the predicate. ${ }^{28}$ In any case, the most obvious things are for everyone, and not just for some.

Sometimes we speak of objective and subjective evidence, terminology which enters into some ambiguity. The objective evidence (or "truth") supports the same object which offers understanding. It is called objective because in it that attention is mainly concentrated on the object which is manifested, and less on the mind which knows it. ${ }^{29}$ Its counterpart is subjective evidence (or "credibility"), which supports the 'evidence considered from the subject'. ${ }^{31}$ This accurate observation points to the core of the same concept of truth and evidence: truth is an adaptation between two extremes (the thing and intelligence), just like evidence, which makes this adaptation obvious. Therefore, what is evident can be considered both in the objective manifestation of the thing, as in the intellectual capture of this manifestation.

c. According to the content, there may be formal or logical evidence, if it deals with the structural correction of propositions (thus, it is evident that if all

\section{Evident is true, is coherent with other truths,} is a necessary reasoning. Evident is the simplest. Requires no justification. It is full of light.

fact of being accepted as credible without any doubt. ${ }^{30}$

Other authors prefer to speak of evidence which designates "the clear ostension, revelation or enlightenment which a fact presents for itself" and of a spiritual 'vision' of evidence which welcomes the relevance or illumination of the object." Both dimensions are correlated and therefore cannot be separated from each other. The expressions objective evidence and subjective evidence can cause distortions, as if they were separable entities. The meaning in such expressions is: 'evidence considered from the object' and

28 Corazón González, R., Filosofía del conocimiento. Pamplona: Eunsa 2002, p. 182-183.

29 According to Corazon, "it is said that this evidence is objective because when it occurs, the subject, as it were, withdraws, disappears from the scene, turns completely into the known and becomes overwhelmed. It is not an extraordinary phenomenon which happens only one or two times in life; it is something that we live daily, because we are continually presented with data observed by the senses, for example, that which we cannot deny: if we see someone leaving a hotel room, we have immediate and direct evidence of that fact" (Corazón González, R., Filosofía del conocimiento. Pamplona: Eunsa 2002, p. 180).

30 Cf. Ferrater Mora, J., Diccionario de filosofía abreviado. Buenos Aires: Ed. Sudamericana 1970, p. 155. elephants have wings and all winged beings fly, then elephants fly); material evidence when it alludes to reality, rather than about the way of saying it (thus, it is evident that it has rained if we see the street is wet); moral evidence when it affirms an irrefutable moral postulate. We could add other types of evidence, after depending on how other content is determined.

d. According to its intensity, various degrees of evidence fit, following what is accepted by Aristotle, phenomenologists and many others. ${ }^{32}$ There are more certain and less certain evidences. A long equation can be evident to a mathematician after hours of deduction, although it is not uncommon that at the end of the road you harbor a doubt about if it is well resolved; a simpler formula will be more obvious to him/her.

\subsection{Characteristics of What is Evident}

Evident is true, is coherent with other truths, is a necessary reasoning. Evident is the simplest. Requires no justification. It is full of light.

31 Brugger, W., Diccionario de filosofía. Barcelona: Herder 1998, p. 226.

32 Corazón González, R., Filosofía del conocimiento. Pamplona: Eunsa 2002, p. 179 speaks of diverse levels "of certainty." 
Once the previous is reviewed, we can now specify which characteristics are evident, work that will serve us later to design the "test of evidence." And the first thing we must do is a fundamental distinction: on the one hand we have the intrinsic characteristics of what is obvious, which are related to its very being and do not depend on external factors or subjects; on the other hand there are external characteristics, which depend on the knower and their circumstances, which will result in more volumes than the first and which will not always be given.

The intrinsic characteristics are the following:

(i) What is evident is true. Therefore, what is false or irrational is not evident although sometimes it has the appearance of being evident.

(ii) Based on the previous, what is evident is coherent with other truths acquired through knowledge; an insurmountable incoherence would demonstrate that in some place error or falsity loom;

(iii) What is evident is a necessary reasoning, in the sense that in all evidence the subject necessarily includes the predicate. ${ }^{33}$ If such an inclusion were contingent it would not be evident. For example, the affirmation "if I kick a ball I score a goal": (after kicking a goal a thousand distinct possibilities exist), is not obvious, but yes, "if I scored a goal, I should have done something so that the ball enters the net" is obvious ("one of my actions" is included in "I scored a goal").

(iv) The most evident is the simplest. ${ }^{34}$ It explains itself; in itself, it does not require argumentation in order to appear in the intellect (although for the uned-

33 Some philosophers, mainly rationalists, have spoken of evidence as "something necessary." It is not clear of what this necessity consists. Ulrici, for example, understands evidence as "the objective necessity of thinking". Sigwart points out that evidence comes from "the capacity to distinguish objectively necessary thinking from what is not necessary" (cf. Eisler, R., Wörterbuch der philosophischen Begriffe. Berlin: Mittler 1904,

"Evidenz"). When Aristotle speaks of necessity (Aristóteles, Física. Trad. de G. Rodríguez de Echandía. Madrid: Gredos 1995, I, 1.2, 18-19) it is more precise: through being evidence something innate, it is necessary that the intellect accepts it. In this case the characteristic of necessity will easily subsume the characteristic of the connaturality of evidence.

34 Thomist in short: If God is the simples, and if God is the most obvious, then the simplest must be most obvious. ucated certain quad se evidence requires a rational discourse)..$^{35}$

(v) What is evident does not require justification, it is indubitable, ${ }^{36}$ it imposes itself though intelligence, without demanding discourse, argument or further proof.

(vi) What is evident is clear, translucent, full of light. It gives way to an immediate and spontaneous understanding. Upon seeing what is directly evident, people should know it, should capture it without anything else. Notice that the luminosity is its own quality of the thing, not of vision: if the stars did not have light, they could not be seen (the view is only perceived as bright).

Regarding the extrinsic characteristics which seem to surround obvious things, we have:

(i) the obvious causes certainty, generates in the knower that subjective security of having adhered to the truth.

(ii) At least in the beginning, what is evident is assumed as something natural - remember Aristotle -, without force, in a peaceful manner, through being innate to the intellect. In what is evident honest intelligence breathes fresh air, and moves with ease. Certain truths can cost (thus, although it is known that harming another is bad, anger can push you to act "against the principles"), but if the intellectual procedure is honest, the will will end up accepting the obvious; on the other hand, a perturbed and licentious mind will look for any excuse to dismiss those evidences which are uncomfortable. ${ }^{37}$

35 Intentionally I do not put like a characteristic of evidence the irreducibility, posed by Finnis, Boyle and Grisez (1987: $100-102,127,131,133)$ and criticized by others, because I admit a gradation in evidence. Certain math formulas are obvious but to capture its evidence it is necessary to know all terms (terms which can be simpler and, therefore, more evident). In fact, Finnis, Boyle and Grisez (Finnis, J., Grisez, G. and Boyle, J., Practical Principles, Moral Truth, and Ultimate Ends. American Journal of Jurisprudence, 32, 1987, p. 119-120) explain that all evident principles of reasoning depend on a prior principle (which, therefore, would be more evident): the principle of no contradiction.

36 Corazón González, R., Filosofía del conocimiento. Pamplona: Eunsa 2002, p. 161-162.

37 Cardona (Cardona, C., Metafísica de la opción intelectual. Madrid: Rialp 1973, p. 158) states that "before these truths 
(iii) As a consequence of everything prior, what is evident seems to be profusely shared. Therefore, it is so related to common sense, understood as a set of generally accepted opinions. The most obvious things must be taken as such by the majority of mortals (although the blind will never be absent unless the undeniable captures it, because the human intellect is weak and can only access quad nos evidence, not the evidence itself).

(iv) What is evident is fertile: concerning evident knowledge other scientific knowledge is well-constructed, and in the practical field, the evident ethical evil," etc.). Only later we arrive at the most complex reasonings of geometry, arithmetic and other sciences. The first truths are more evident, simpler, more clear, more shared through human kind and with greater certainty: ${ }^{38}$ the first apprehensions are clearer than the judgements, the first judgements are simpler and clearer than the articulated reasonings, a reasoning is easier to verify than a system of thought composed of many reasons. Conversely, proof does not always show strong evidence: it is not always clear who confesses to be a criminal, nor does any testimonial statement generate great certainty. A jury can be divided by

\section{Evident things cause certainty, are assumed} as something natural and tend to be

\section{profusely shared. Evident is fertile.}

principles generate a more successful culture and a greater well-being. "Through their fruits you will know them," was once said by the most celebrated Israelites.

The mentioned characteristics allow gradualness, because what is evident is an analogous concept. Human knowledge is constructed in layers: initially there are the first apprehensions which we capture from reality (e.g. "there are things," "I have hands," "I exist," etc.), then the simplest judgements appear ("this is good," "we have to do good," "I have to avoid

which arrive soon, tyrannically imposing with its unsuspecting evidence, maybe violating other convictions and attitudes, we tend to react with disgust, accepting them only provisionally, while we do not discover its weak side. In general, this occurs when it's about truths which have consequences and - for more speculative understandings - when they are consequence of some other affirmation of that which we disagree." Intelligence does not think in an autonomous way, but in play with willpower. "It seems natural and positive that our willpower intervenes when the work of reason affects life, in its totality of feeling or in points which determine the conduct. What is not natural or positive is ignore this intervention intending that intellect works only with rational and scientifically proven evidence." listening to the victim or criminal, and even a video can deceive us.

Evident things cause certainty, are assumed as something natural and tend to be profusely shared. Evident is fertile.

\subsection{Function of Evidence}

The main function of evidence is to be a "criterion of truth". ${ }^{39}$ A criterion of truth is the means from which the truth is made clear. If we doubt an affirmation and want to verify if it is true, we have to check it with other more certain, clear and undoubted knowledge. At the end of the road we must check everything with what is more evident: there is no prior instance of thought which appeals to judge the value of the known: "that

38 Through these common topics we can talk with others. If there were no common ideas among human beings, the dialogue (which presupposes ideas and signs of those common ideas) will turn out to be impossible. The fact that we can speak shows that there is a common substratum among human ideas (reflected later in words, signs and symbols).

39 In this sense, cf. Millán-Puelles, A., Obras completas, t. VII. Madrid: Rialp 2015, p. 276-279. 
instance, if it existed, would be by definition irrational or prerational" ${ }^{40}$

All science is constructed to confront hypothesis with evidence that has been previously acquired. ${ }^{41}$ All scientific knowledge is arrived upon from what is evident. If it were not like this, science would be pure fiction, pure fantasy. Science is built upon the secure pillars of the undoubted, its hypotheses and theories do not start from nothing, and they gain support when contrasted with what is the obvious. As Polo would say, "the obvious is that which awakens, the only thing that avoids running through the branches, the superficiality (...) it is clear that philosophizing requires not slipping on the obvious. Not knowing what is paramount in things consists precisely of not starting to focus on what is obvious." ${ }^{42}$ We cannot "pretend that philosophy is a 'new start,' as if no valid prior knowledge existed" ${ }^{43}$ The same must be said of legal science, which cannot rise above emptiness either.

In order to not fall in absurd idealism or absolute relativism where all and nothing can be right, the elaboration of the legal doctrine must be built on the primary concepts and principles extracted from the rock of an evident reality. In another place we have worked on the topic of legal concepts, which define the law to a good extent. ${ }^{44}$ But as we saw there, the legal conceptions do not appear through the art of magic but are formed progressively. First the immediate knowledge of external reality (of people, things,

40 Corazón González, R., Filosofía del conocimiento. Pamplona: Eunsa 2002, p. 161.

41 Cf. Millán-Puelles, A., Obras completas, t. VII. Madrid: Rialp 2015, p. 276.

42 Polo Barrena, L., Curso de teoría del conocimiento, vol. I. Pampona: Eunsa 2004, p. 61-62.

43 Artigas, M., Filosofía de la ciencia. Ansoáin: Eunsa 1999, p. 17.

44 Cfr. Riofrío Martínez-Villalba, J.C., Síntesis de la teoría de la pirámide invertida. Ponencia del I Congreso de Filosofía del Derecho para el Mundo Latino. Alicante 2016, p. 13 y ss.; Riofrío Martínez-Villalba, J.C., Las causas metafísicas como fuentes del derecho. Revista Telemática de Filosofía del Derecho, 15, 2012b, p. 277-282; Riofrío Martínez-Villalba, J.C., De la pirámide de Kelsen a la pirámide invertida. REDESG Revista Direitos Emergentes na Sociedade Global, 2(2), 2013, p. 455-460. and the environment) must be forged, because without this knowledge there is no possibility of reasoning, nor any intellectual conclusion. In order to have conclusive reasoning first it should have judgements, and in order to have judgements before there must be those obvious notions directly captured from reality. Once extramental reality is known, the intellect will be able to draw the first legal conclusions, which make up what we call natural juridical conception. For example, someone who knows that the electromagnetic spectrum is limited will understand the doctrine of the scarce resources of telecommunications law and will understand why the State holds unique powers to distribute the frequencies. Someone who understands sexual human nature and its natural purposes will rapidly grasp the first principles of matrimonial law. Ignorance of these fundamental legal issues will deal a mortal blow to the law, because it is here where legal reflection begins. Without knowledge of human purpose, human freedom remains reduced to a whim, a passing emotion, and, finally, a useless passion (as Sartre maintained); on the contrary, an accurate understanding of reality will give wings to the rights and freedom. All the very first principles of law come to us through the channel of evidence. However, the derived principles seem to be less evident. ${ }^{45}$

Over the last few years the debate about the "symbolic function" of laws began. ${ }^{46}$ North American law has had some welcoming of the labeling approach or "theory of definitions," which emphasizes the important role which labels or labels with which different types of things are rated. The thesis has in its favor showing how the changes in normative language are not always products of chance, but often obey political, social or cultural mutations which good or bad

45 Thomas Aquinas wrote that "we must observe that as the intellect naturally and of necessity adheres to the first principles," and not only to those but also "there are some propositions which have a necessary connection with the first principles" Tomas de Aquino, Suma Teológica. París-Italia. Traducción al castellano de BAC. Suma Teológica de Santo Tomás de Aquino, 4a ed. Madrid: BAC 2001, I, q. 82, a. 2.

46 E.g. Hegenbarth, Hill, Ryfell, Noll, Amelung; cf. Hassemer, W., Derecho Penal Simbólico y protección de Bienes Jurídicos. E. Larrauri (trad.). En J. Bustos Ramírez (ed.). Pena y Estado. Santiago: Conosur 1995, p. 23-36. 
introduce new definitions of reality. Some supporters of this theory are rather radical: for them the "legality" or "unlawfulness," the "lawfulness" or "illegality," the "validity" or "invalidity" of the rules and legal acts are no more than labels or moving categories which only make sense when they defined or typified; they would lack, therefore, any ontological or factual justification. Such radical approximation to normative language ignores what is evident, omits just the first step of reasons: (i) because the most evident is so luminous that it blinds our eyes; ${ }^{48}$ and (ii) because a less than honest intellect tends to justify the unjustifiable. ${ }^{49}$

In the relativist period we went through, where all and nothing is valued, it has become essential to rescue the obvious. Orwell already observed that we have sunk to such a depth that the reformation of the obvious has become the primordial obligation of intelligent men. ${ }^{50}$ And this is what we propose.

\section{"We have now sunk to a depth at which the restatement of the obvious is the first duty of intelligent men" (Orwell)}

knowledge which comes through sensitive contact with reality, from which the intellect extracts the first concepts; if human language (to which concepts are attributed) was not anchored in reality, any communication would be vain, the rules, written or verbal, would have no legal effect. It is necessary to start from concepts linked with evident reality.

We conclude, then, that in law the formulation of the evident is crucial in order to draft real legal definitions, to detect the natural purpose of people and things, to discover the first principles of law, as well as to develop a healthy realistic hermeneutic and to verify if the conclusions reached by the doctrine are valid by coinciding it with reality.

\section{The Proof of the Obvious}

Now we will investigate how to prove or detect what is obvious, first in a generic manner and later in the field of law. At first sight, this seemed to be a futility ${ }^{47}$ because, as we saw, the proof of what is obvious is precisely its own evidence: the obvious is clear, does not require justification. However, we think that this task turns out to be very necessary nowadays for two

47 "It is ridiculous to pretend to demonstrate that nature exists," says Aristóteles, Física. Trad. de G. Rodríguez de Echandía. Madrid: Gredos 1995, 1.6.
"We have now sunk to a depth at which the restatement of the obvious is the first duty of intelligent men" (Orwell)

\subsection{The Possibility of Proving the Obvious}

It has been repeated many times that what is obvious does not require proof, that it is "irreducible," that it imposes itself on the intelligence without the necessity of additional evidence. Proof of the obvious

48 The idea is from Aristotle: before the evidence of nature our understanding makes the same of the owl in front of the rays of the sun (Aristóteles, Metafísica (trad. de V. García Yebra). Madrid: Gredos 2012, II, Ia c.1 n.2: BK 993b9). It is also recorded in the Tomas de Aquino, Suma Teológica. París-Italia. Traducción al castellano de BAC. Suma Teológica de Santo Tomás de Aquino, 4ª ed. Madrid: BAC 2001, I, q. 1, a. 5 , sol.

49 Vid. Stated in footnote 35.

50 "We have now sunk to a depth at which the restatement of the obvious is the first duty of intelligent men" (Orwell, G., Review of Power: A New Social Analysis by Bertrand Russell. En J. Carey (ed.) George Orwell. Essays. New York: Everyman's Library 2002, p. 107). The same author complained that "All political thinking for years past has been vitiated in the same way. People can foresee the future only when it coincides with their own wishes, and the most grossly obvious facts can be ignored when they are unwelcome". 
would call for, among other things, evidence which then should also be justified. The fish bites its tail. Aristotle showed that whoever wants to negate the principle of non-contradiction should use it, and use it as if it were valid; otherwise it is impossible to do so any other way. Basically, if we required proof of the obvious, we would have to appeal to other more direct and immediate knowledge, and, because it is so, would be just evident. We would then fall on an ad infinitum solution, where you always sought and never found.

Speaking with rigor, what has been stated is only valid for the most obvious things. The most obvious is indemonstrable. But it follows that there are less evident things which are proven with the most obvious. That is how math equations occur (self-evident), which are "tested" with the most obvious: no one proves the equality of $1=1$, but with equality, more complicated equations are tested.

The most evident certainly cannot be proven in recto, because the cause of what is evident can never be demonstrated, it will never be deduced from another prior postulate (but that would not be so obvious). But nothing prevents that it can argue its existence in oblicuo, attending to its effects ${ }^{51}$ or demonstrating how absurd it would be to deny the obvious or affirm its opposite. In any case, we have to accept that oblique tests will not be as conclusive as direct tests.

In particular, we think that indirect evidence can be made by checking whether the characteristics of the evident are verified in the sub examine (sub-statement). If we find that an affirmation is simple, clear, incontestable, accepted by all, we will probably face something very obvious. On the contrary, if reasoning

51 The same idea is stated in the Tomas de Aquino, Suma Teológica. París-Italia. Traducción al castellano de BAC. Suma Teológica de Santo Tomás de Aquino, $4^{\mathrm{a}}$ ed. Madrid: BAC 2001, I, q. 2, a.2, sol., where it is stated that "Demonstration can be made in two ways: One is through the cause, and is called a priori, and this is to argue from what is prior absolutely. The other is through the effect, and is called a demonstration a posteriori; this is to argue from what is prior relatively only to us. When an effect is better known to us than its cause, from the effect we proceed to the knowledge of the cause." Later he concludes that the existence of God "is not self-evident to us" but "can be demonstrated from those of His effects which are known to us". is confused, rarely articulated, unknown by experts, we will very well be faced with something lacking evidence. Consequently, we have two ways to verify if something is evident: a positive one, which confirms the existence of characteristics of the evident to affirm "this is evident," and another negative, which only verifies that the characteristics are not observed which is to say, "this is not evident." Let's analyze them.

\subsection{The Negative Test}

We will begin with the negative route, which is the simplest. It does not intend to point out which elements are false, obscure, complex or rare, but only determine which statements are not evident. If an affirmation did not pass the negative test, the conclusion simply would be that it is not evident quad nos.

According to the negative test, it is not evident: (i) that which has demonstrated to be false or different from reality, the absurd, the irrational, by lacking in truth; (ii) that which contradicts other more evident truths; (iii) that which contradicts itself; (iv) the complex or overly articulated reasons, the rare or strange ideas, and all that is not captured immediately, through lack of simplicity; (v) that which is only accepted through faith, through lack of auto-justification; (vi) that which is not captured from the start, the invisible or untenable, through lack of clarity; (vii) the uncertain or poorly expressed statements, the superficial, the mere options and perceptions, but they do not cause certainty in those who listen to them; (viii) the imposed ideology through those who have power, the doctrines bombarded by massive public campaigns against common beliefs, and, in general, that which causes the intellect to reject, because it does not arrive in a rational and natural way to the subject, but imposing itself with some force; (ix) neither do the ideas shared only through small groups, specific sectors of society or via a few generations seem evident, because the obvious spreads in the most profound way; and, finally, (x) those affirmations from which fatal things follow for society.

The assumptions (iii) to (x) only define that an assertation does not seem evident, although eventually it would be true, and could be proven through empirical or deductive processes, as it has happened with the existence of Higg's Boson. Assumptions (i) and (ii) also determine the falsity of the claim. 


\subsection{The Positive Test}

After passing the negative test we must perform the positive test. Unlike the previous, here we look to determine if something is evident. The conclusion of the positive test will rarely be apodictic, but at least it will yield an approximate criterion of evidence. The test is carried out by verifying if the intrinsic and extrinsic characteristics of the evidence are met: the more characteristics that are verified in an affirmation, the greater the evidence will be.

\section{a. The Verification of Intrinsic Characteristics}

The verification of Intrinsic Characteristics of the evident (truth, coherence, necessity of reasoning, simplicity, unnecessary justification and clarity) represents not such a small challenge. The most obvious things simply cannot be tested in a direct manner, because in order to test them we would need to go to something even more evident and prior. ${ }^{52}$ The less evident something is (e.g. derived truths) the easier it will be to prove its evidence through other previous evidences.

If the first three characteristics are verified (truth, coherence and necessity), what is said is evident, because it fulfills all the essential elements of evidence. If we do not verify the three in unison, but if there are various intrinsic characteristics, there will be serious signs that the statement is evident.

Let's analyze them:

(i) Truth. The truth is tested by comparing the affirmed with the reality. Things are reflected in our intelligence, like in a mirror: if the reflection is bad, there will be no truth. The confrontation of idea-reality can be made in a theoretical or empirical manner, through the hypothetical-deductive method, the inductive, among other methods. ${ }^{53}$

52 In any case, it could be found. Think about the cogito ergo sum, reasoning that cannot be done without previously knowing those three concepts (the concept of "I know," "then," "I exist"). In reality, that first Cartesian idea is not the first at all: before must be the idea of "knowing," and even before the idea of "prior-subsequent," and much before the idea of "existence."

53 About the variety of methods, see Riofrío Martínez-Villalba, J.C., La selección del método en la investigación jurídica. 100 métodos posibles. Revista de Educación y Derecho, 12(2), 2015, 1-27.
Finnis, Grisez y Boyle ${ }^{54}$ in some way have suggested this path. When defining which practical principles are evident, they mentioned that this probably could be done through studies about human beings that accurately detect natural inclinations and using anthropological studies which examine the motives and purposes of behaviors in all cultures.

The test of truth is the most difficult among the most obvious things and ends up being absolutely impossible in evidence of simple apprehension.

(ii) Coherence. Here it is necessary to compare the affirmed with other already proven or evident affirmations. If an affirmation agrees with all the knowledge known in certainty, it is probable that it is true and evident.

With the simplest and most evident truths maybe the only thing that fits is showing how absurd it would be to affirm the contrary. This is the form in which Finnis, Grisez and Boyle ${ }^{55}$ argued in favor of the evidence of the seven goods which they considered basic. Finnish $^{56}$ states that «although it is not possible to demonstrate the basic goods as goods, it is possible to demonstrate that to deny the basic goods is to fall into that philosophical quagmire of self-refutation; the basic goods cannot be coherently doubted».

The reduction of absurdity does not directly prove the truth of the claim, much less its evidence, but makes it more probable and verifies some of its coherence.

(iii) Necessity of Reasoning. According to the classics, if the predicate is found in the subject, what is stated is evident. This occurs in mathematical equations and in many affirmations. We are facing a conclusive proof of evidence, of course, if it is proven. The problem here is that generally we do not always have a complete idea of the extremes of the claim. Therefore, Aquinas, after

54 Finnis, J., Grisez, G. and Boyle, J., Practical Principles, Moral Truth, and Ultimate Ends. American Journal of Jurisprudence, 32, 1987, p. 113.

55 The authors titled this test the "Dialectical Defense" of the evident. Finnis, J., Grisez, G. and Boyle, J., Practical Principles, Moral Truth, and Ultimate Ends. American Journal of Jurisprudence, 32, 1987, p. 111.

56 Finnis, J., Scepticism, Self Refutation and the Good of Truth. En P.M.S. Hacker and J. Raz (eds.). Law, Morality and Society. Essays in Honour of H.L.A. Hart. Oxford: Clarendon Press 1977. 
affirming that the existence of God is self-evident in itself since in God the subject and predicate are the same, he observes that "because we do not know the essence of God, the proposition is not self-evident to us; but needs to be demonstrated". ${ }^{57}$

(iv) Simplicity. The simplicity of things is found by quantifying the parts which comprise them. The simplest knowledge is that of "simple apprehension," where the mind imagines what is captured by the senses. Upon seeing, hearing, smelling or touching we form an idea of what things are. The senses do not make mistakes, unless they are atrophied or suffer some type of illness; it is the mind which composes the images, sounds, smells, etc. can make mistakes. A concept depends on many apprehensions, and a judgement (A is B) requires more than a concept. Therefore, the judgement is less simple than the concept, the concept less simple than the "simple apprehension." Many judgements produce reasons, and the connection of reasons generates systems of thought. Here you have the application of Ockham's razor, through which two theories of equal conditions have the same consequences, the simplest theory has more probabilities of being correct than the complex one: ${ }^{58}$ we have to go to the simplest and evident truths first, it is not convenient to begin with the complex and rare..$^{59}$

57 Tomas de Aquino, Suma Teológica. París-Italia. Traducción al castellano de BAC. Suma Teológica de Santo Tomás de Aquino, $4^{a}$ ed. Madrid: BAC 2001, I, q. 2, a. 1, sol.

58 Cf. Audi, R. (ed.), Ockham's razor. The Cambridge Dictionary of Philosophy, 2a ed. New York: Cambridge University Press 1999; Thorburn, W., The Myth of Occam's Razor. Mind, 27, 1918, p. 345-353.

59 Leibniz, Kant, Menger, Einstein and many others have criticized the reasoning of Ockham for being too superficial. Sometimes more elements are necessary to explain reality. Against the assertion that pluralitas non est ponenda sine necessitate (plurality must not be proposed without necessity), Kant responded in his Critique of Pure Reason that "the variety of beings shouldn't necessarily be diminished" and Menger pointed out that "it is vain to do with less that which requires more." Cf. Maurer, A.A., Medieval Philosophy. New York: Random House 1962 and Maurer, A.A., Ockham's Razor and Chatton's Anti-Razor - Mediaeval Studies, 46, 1984, p. 463-475. We consider the reason of Ockham does not work to find the truth, neither like a method for delineate
We have to keep in mind that ideas enter the human intellect in layers: the first ideas are structured in forma mentis, a mold that will accommodate or impede subsequent knowledge. The simplest ideas tend to be better served to articulate more complex thoughts. The simple tends to measure and judge the complex.

(v) Unnecessary Justification. The justification of the obvious is a rather tedious task, and the direct justification of the most evident is an impossible undertaking, because the self-evident finds itself in its justification. "I exist," "there are five people here" are truths that we know via simple apprehension; "the total is greater than or equal to the part," $2+2=4$, are truths that we know through intellectual evidence. The evident is axiomatic. The very impossibility of denying or proving the veracity of the affirmed says something about its evidence.

(vi) Clarity. Clarity is an essential characteristic of the obvious. We repeat that the evident implies the presence of a reality as unequivocal and clearly given to intelligence. The extremely evident is extremely luminous to intelligence, which through its clarity can see. A legible essay, a clear exposition, good intonation, a complete presentation, etc. help to realize the plentitude of evidence. However, the source of this characteristic is more difficult to prove; it could be done by examining the degree of understanding acquired in those who have heard of some theory, assertion or fact.

\section{b. The Verification of Extrinsic Characteristics}

The simplest proof that something is evident is made by verifying if it has manifested itself as externally evident. It is the test for the effects. The characteristics which the obvious tends to gather (certainty, connaturality, generalized knowledge and fertility) can be easily verified through empirical tests (exams, interviews, statistics, etc.) which define how true and natural an affirmation is to the public and how many shares it.

If the three extrinsic characteristics in an affirmation are confirmed, it is probable that it is evident. Let's study them:

theories or hypothesis, but can have a modest use to detect if something is obvious or not. 
(i) Connaturality. We say that, at least when the obvious is recently captured, that it assumed to be something natural. One does not notice: nobody states, "it's true, I have seen the moon." I have just seen it. On the one hand, faced with an affirmation that is not evident (which tends to be obscure and complicated) the public will be afraid to accept it. The ideas which require a constant and mass propaganda to establish themselves in a society do not tend to be evident, precisely because they were not introduced naturally to people. That its acceptance causes foul language or embarrassment (at least initially, before people or society have self-excused) neither tends to be evident (what happens with many sexual behaviors). On the other hand, over years that which peacefully belongs to the "common sense" of a society tends to be evident.

(ii) Certainty. The perception of the transparent has as an effect that the sensation of security of having known that it is called "certainty." Certainty does not generate doubts: who sees the moon does not question if he/she has seen it. On the other hand, when faced with uncertain doubts they naturally rise to the surface: "is it true that I have seen a ghost?" Here we refer to serious doubts, which in morals is called "positive doubt": that which houses the possibility of the contrary to what is believed exists. You can always muddle over superfluous doubts like those of the evil genius Descartes, but those do not cause true uncertainty but to a madman.

Connaturality and certainty can be proven and by tested by the sense of security and naturality with which persons received the information. But for such a test there will have to be selected a very good focus group, because "things are revealed to men in various ways, according as they are variously disposed". ${ }^{60}$ A doctor will experience more difficulty grasping

60 Tomas de Aquino, Suma Teológica. París-Italia. Traducción al castellano de BAC. Suma Teológica de Santo Tomás de Aquino, $4^{\text {a }}$ ed. Madrid: BAC 2001, III, q. 55, a. 4, sol. Then the Summa explains how the diversity occurs: "for, those who have minds well disposed, perceive Divine things rightly, whereas those not so disposed perceive them with a certain confusion of doubt or error: 'for, the sensual men perceived not those things that are of the Spirit of God,' as is said in 1 Co 2, 14". the evidence of physics equations than an engineer, because they are not a part of his science. A wimp or someone who is fickle will have less certainty of what is known and more fear of not having arrived at the truth. ${ }^{61}$ Whoever is full of prejudices against a subject or current of thought will have difficulty grasping the truth which comes from that source. In these examples we see various obstacles which reduce the effects caused by the evidence: there are obstacles external to the evidence that do not undermine its existence, but its manifested effects (it avoids the external manifestation of the obvious).

When it comes time to prove the certainty and naturalness with which information is received we have to select a more educated, coherent ${ }^{62}$ and sensible public, avoiding the crazy and foolish people. ${ }^{63} \mathrm{~A}$ panel of physics experts will be able to say more reliably whether an equation is evident or not; the most serene and calm people probably will be in a better position to capture the light of evidence than that exalted and biased by a position.

(iii) Generality. Whether or not the aforementioned external obstacles exist, it seems clear that the most obvious things will be grasped by a greater number of intelligences. Something widely shared by different cultures and generations will show greater betas of evidence. Many values hold unbeatable evidence: think about loyalty, veracity or honesty, so widely shared in cultures throughout time. No culture has infidelity, deceit, theft, or fraud as a value (although you will always find a rare bug, a blind man unable to grasp the obvious, who will make any leitmotiv from any stupidity).

While most people share an affirmation and while less contradict it, the more likely there is evidence. The

61 See footnote 52.

62 Whoever claims to be sure of a doctrine, but does not live according to it, in reality is insecure about it.

63 In fact, theological science considers the life of the saints and their doctrine as locus theologicus, that is to say, as a source of scientific knowledge. These theological places help to understand divine science, "but a new public revelation they do not accept as pertaining to the divine deposit of faith" (Concilio Vaticano II, Lumen Gentium. Vaticano: Editrice Vaticana, n. 25§4; cf. Concilio Vaticano I, Constitución dogmática Pastor Aeternus. Vaticano: Editrice Vaticana, n. 4); that is why they are corroborating sources, not constituents of revelation. 
opinion of the majority is no the truth, not less the evidence, but a piece of evidence among others. Only here it can be argued that which is naturally shared as safe by the majority of people shows serious signs of evidence. Although it is not apodictic, the generality says something about the evidence. It is used by those looking to base ethics in the shared values of society, and something is right in such work. ${ }^{64}$

Generality it is perhaps the simplest characteristic to prove and it can be done in different ways:

- Statistics. Statistics show how many have accepted a certain thesis at the time and how many have been its detractors. ${ }^{65}$ It seemed to be quintessential proof of evidence. However, when we speak of evidence, the size of the audience is very large (all people of all times), which demands a sample which is difficult to achieve; and, as we know, if we reduce the sample, we reduce the viability of the results. On the other hand, the statistics are not always available, nor are they always done well. ${ }^{66}$

- Historical Documents. The annals of history collect many centuries-old and immemorial customs which reflect the way people think for centuries. The words also possess historic traces and their etymology allows us to detect how ancient people understood them at that moment, only in that moment closest to the first absolute apprehension related to the term. Additionally, we have sayings which repeat and reformulate

64 However, moralists would be wrong if they did not go further, only maintaining the opinion of the majority. It is good to know what each country values, but then you have to study the underlying reasons why each thing is considered valuable. If we do not reach the ontological and practical levels, we remain in the moral of the majority, in a relativism lacking of any sense, incapable of surviving just one generation.

65 A basic principle of statistics is to count both the data in favor, and the data against it. One piece of data compliments and corrects the other.

66 Polo Barrena, L., Quién es el hombre. Madrid: Rialp 1991, p. 34 observes that "physicists say that we turn to the statistical explanation when we do not have another, because the statistical explanation is the weakest. In addition, statistical explanations have a limit, since not everything can be explained statistically. When many factors enter into the calculation, there is no way to establish the statistics. This is technically called the 'white noise." in different generations: the sayings are a privileged formula of transmitting evident truths.

It is also possible to access the feelings of our ancestors through their most distinguished interlocutors: the classis artists, the best writers and geniuses. From prehistory we do not have letters, but art, which we are still trying to decipher. With the appearance of writing we can trace what our first parents thought. Homer through the Iliad and the Odyssey, Sophocles with Antigone's tragedy, and Virgil through the Aeneid and the Bucolic, speak to us about thought during the VIII, V, and I centuries B.C. Literature and classic music are different from fashionable novels and ballads because fashion is fleeting, while the classic pleases an infinite number of generations who find in that art something beautiful, true and sublime. - Art. Art is a good vehicle for expressing truths, both the most obvious and simple, and the most profound and difficult to understand. Thomas Aquinas pointed out that "just as human reason fails to grasp poetical expressions on account of their being lacking in truth, so does it fail to grasp Divine things perfectly, on account of the sublimity of the truth they contain: and therefore in both cases there is need of signs by means of sensible figures" (Summa Th. I-II, q. 101, a. 2, ad 2). Such a representation many times takes us from the easy to the profound. As Kahil Gibran said, "art is a step from what is obvious and well-known toward what is arcane and concealed." ${ }^{67}$

But not all art works in the same manner to express the obvious, because the expressivity of art is very variable and because artists do not always know what they represent. Architecture, building decorations, goldsmithing and costume jewellery, music without lyrics, together with absolutely abstract art, fail to manifest but a joining of sensations which rarely can be described as true or false. landscape painting shows with its tonalities how things are valued, but much does the one representing the mythical or real characters, caring for their luminosity and gala, or filling them with shadows and cold nuances. A good portrait expresses more than a photograph. Something similar happens with a sculpture when it keeps feminine pro-

67 Gibran, K., The Wisdom of Gibran: aphorisms and maxims. New York: Philosophical Library 2010. 
portions or shows the strength of heroes, proclaiming day and night the ideal of beauty or civic values.

More expressive is the art which moulds language to show values, principles or ideas: poetry, songs with lyrics, thick literature, theater and the movies. Poetry encloses little truth, but may contain that which seems to the poet to be evident and feels driven to proclaim through the feeling of security that produces the idea. In a certain sense, the evident is scarce. Songs also manifest the truth observed by musicians: certainly, there we will not find the theorem of Tales, nor of Bayes, nor of Pythagoras, but the truth of emotions, that of the impetus of the heart. Many ballads and boleros speak very well of love, on occasion better than the great philosophers. Aristotle wrote excellent lines about friendship, but more convincingly a love song, a novel or a friend's life of flesh and bones. While describing the superficial, to capture the impressions and produced emotions, to feel the reality of interpersonal relationships, and to describe some other phenomenon, artists excel in multiple aspects of philosophy.

(iv) Good Fruits. Here only attends to the effects of kindness. When something is based on a well-developed science, which is to say, when without that piece various sections of that science fall, that piece normally is evident. In practical reasoning the same occurs, but also there we have to verify the positive or negative effects. An anti-Semitic principle is capable of constructing a Nazi morality in good rule, but that does not mean that the starting principle will be evident. Only the practical principle that has generated a culture of peace, well-being and harmony will seem evident.

Authors such as Finnis, Grisez and Boyle ${ }^{68}$ have also appealed to this path when, upon speaking of the primary principles they pointed out that although there is no direct proof of their evidence, it is possible to appeal to "dialectical arguments" to demonstrate that its negation carries unacceptable consequences.

\subsection{Evidence in the Law}

Evidence is a corner where the procedural law and theory are found. Procedural law is interested in defin-

68 Finnis, J., Grisez, G. and Boyle, J., Practical Principles, Moral Truth, and Ultimate Ends. American Journal of Jurisprudence, 32, 1987, p. 111. ing what tests contain sufficient evidence to judge in a certain way, while the theory of law is interested in proving what is truly fair, lawful or legitimate in each case. In this last type of evidence - more theoretical and less factual - we will dedicate ourselves to this next.

In order to define the most fundamental structure of law, in order to detect which are its primary principles, its most secure and indubitable directives, jurists of all times have turned to a series of institutions (also within the judicial processes) that show which are the more generalized legal concepts. ${ }^{69}$ Specifically, we are speaking of customs with the greatest longevity, aph orisms and maxims, traditions, common opinion and the constant doctrine of doctors.

Juliano considered the inveterate custom forced as much as the law, ${ }^{70}$ in a system where the law already has its weight. In fact, an immemorial custom repeated in the majority of cultures probably manifests a point of obvious legal truth. Think, for example, about the diverse cultural forms of celebrating matrimony, where nevertheless, care is taken that the man and the woman always have a moment to express their will in a clear and free manner. The union of wills is not something incidental or accessory, but nuclear to the marriage, something undoubtedly evident.

Other customs with longevity and several legal traditions would also be able to manifest obvious rights or obligations, while there are no opposing uses or traditions in another time or place. Something similar could be said of common opinion and legal practices, when they turn out to be very widespread: if all citizens understand the law in a certain way, if everyone applies it in a certain way, ${ }^{71}$ we face an unanswered point of law. ${ }^{72}$

69 Cfr. Riofrío Martínez-Villalba, J.C., Fines, valores y principios comunes a la propiedad intelectual, al derecho a la competencia y a otros derechos. Ius Humani. Revista De Derecho, 3, 2012a, 37-50.

70 Inveterada consuetudo pro lege non immerito custoditur (Juliano, Digesto I.3.32.1).

71 The Roman genius pointed out that laws resemble the old customs confirmed by consensus (diuturni mores consensu utentium comprobati legem imitantur, in Inst. 1.2.9).

72 We also remember that Paulo, and later many other jurists, maintained that the custom is the best interpreter of the law. Optima est legum interpres consuetudo (Paulo, D. 1.3.37). See also X. 1.4.8, where he states that consuetudo est óptima 
The common and constant doctrine of doctors tend to present various characteristics of a deeper knowledge of evidence: clarity, certainty, and qualified generality. Not in vain in international processes renowned lawyers "prove" what national law is, when they all share a common opinion about a specific issue. Precisely for that reason, who attacks that test has to intervene presenting other experts of equal fame that sustain the contrary.
The problem with aphorisms are their simplicity: although this highlights its evidence, its application is not always adequate to all cases which cross the mind. Facing an uncomfortable aphorism, the rhetoric recommends defending itself by invoking a contrary aphorism, which does not stop being but a show solution. In the end, they will have to carefully clarify which legal principle applies adequately to the case and

\section{Old aphorism and maxims of law shows the best guarantees of the evident.}

Old aphorisms and maxims of law show the best guarantees of the evident.

The doctrinaires and lawyers also frequently use adages, sayings, aphorisms, brocades and maxims of law, to support the claims that they make in their writings and allegations. And this is extremely convenient, because they present a good dose of evidence. Pacta sunt servanda, ad impossibilia nemo tenetur, alterum non laedere, suum cuique tribuere... are indubitable truths which are studied at the beginning of the career and create a base upon which subsequent legal knowledge will settle. An aphorism is the genius of an illustrious jurist, who pronounces himself/herself synthetically upon a specific point of law, repeated later by subsequent generations who have immediately found in that phrase the clear expression of some true. These maxims show the best guarantees of the evident: they are extremely simple, they have great clarity, they do not require great justification, they assume a natural way, they are shared by scholars and laypersons, they pose a certain capacity to settle controversies and are cited in treatments in order to structure all subsequent knowledge on them. Its abundant use in different eras, cultures and legal systems denotes an overwhelming generality, typical of the most evident. ${ }^{73}$

legum interpres and Coke when he says that optimus interpres legum consuetudo (Institutes, II: 18 y 228).

73 Naturally not all phrases of ancestors come to be obvious maxims, because not all of them have the same type of dif- which must be rejected. ${ }^{74}$ If, however, two clearly contradictory aphorisms arise on exactly the same point of law, it is probable that we are not faced with something obvious, and that only one of them is justified.

\section{Conclusions}

We can summarize the conclusions of this paper, as follows:

1. According to what was wrote, it is evident that clear knowledge immediately and directly captures what things are. If differs from certainty, from faith, experience, intuition and common sense.

fusion, simplicity, clarity and certainty. Therefore, we greatly appreciate the particularized study of actual aphorisms made by Domingo Osle, R., Ortega, J. y Rodríguez-Antolín, B., Principios del derecho global. Cizur (Navarra): Aranzadi 2003.

74 As Otaduy states (Otaduy, J., En Comentario Exegético al Código de Derecho Canónico, v. 1, $3^{\text {a }}$ ed. Pamplona: Eunsa 2002, p. 364), "many of the legal phrases of traditional authority, many of the 'regulae iuris' or 'brocarda,' formulated as proverbial axioms or legal apothegms for the interpretation of the law, have a very labile use, which can be contradictory if used without discernment; in fact, many of them are contradictory to each other, because they were born to solve issues which merited very diverse solutions. They give some help for the interpreter, in the sense that they formulaically condense a solution of experience, valid for some cases. But they do not spare the interpreter the fundamental task of unraveling the particular cause that is discussed." 
2. The obvious shows ten characteristics. Its intrinsic characteristics are: truth, coherence, necessity of reason, simplicity, its unnecessary justification and clarity. Its extrinsic characteristics are: certainty, innateness, generalized knowledge and fertility.

3. A method was designed to detect the obvious, which consisted of a positive test which verifies if the ten mentioned characteristics are fulfilled, to conclude "this is evident," and in a negative test that analyzes if they are not met to infer "this it is not evident."

4. Certain sources of law manifest the characteristics of the evident in a special way. Specifically, the longest-standing customs, common opinion, constant and common doctrine of doctors; but above all, what has the most nuances of evidence, are the aphorisms, brocades or maxims of law, which condense in a simple phrase an uncontested affirmation of law.

\section{Bibliography}

Aristóteles, Del sentido y lo sensible de la memoria y el recuerdo.

Francisco de P. Samaranch (trad.). Madrid: Aguilar 1980.

Aristóteles, Ética nicomaquea. Trad. de J. Pallí Bonet. Madrid: Gredos 1985.

Aristóteles, Física. Trad. de G. Rodríguez de Echandía. Madrid: Gredos 1995.

Aristóteles, Metafísica (trad. de V. García Yebra). Madrid: Gredos 2012 .

Artigas, M., Filosofía de la ciencia. Ansoáin: Eunsa 1999.

Audi, R. (ed.), Ockham's razor. The Cambridge Dictionary of Philosophy, 2a ed. New York: Cambridge University Press 1999. Bradley, G.V. and George, R., The New Natural Law Theory: A Reply to Jean Porter. The American Journal of Jurisprudence, 39, 1994, 303-315.

Brugger, W., Diccionario de filosofía. Barcelona: Herder 1998.

Cardona, C., Metafísica de la opción intelectual. Madrid: Rialp 1973.

Coke, E., Institutes of the Laws of England, t. II. Ann Arbor: University Microfilms International 1642/1977.

Concilio Vaticano I, Constitución dogmática Pastor Aeternus. Vaticano: Editrice Vaticana.

Concilio Vaticano II, Lumen Gentium. Vaticano: Editrice Vaticana. Corazón González, R., Filosofía del conocimiento. Pamplona: Eunsa 2002.

Cruz Cruz, J., Intelecto y razón. Las coordenadas del pensamiento clásico. Pamplona: Eunsa 1982.
Cruz Prados, A., Historia de la filosofía contemporánea. Pamplona: Eunsa 1987.

D’Alambert, J., L'Encyclopédie ou Dictionnaire raisonné des sciences, des arts et des métiers 1739.

Descartes, R., Meditationes de prima philosophia. Hay traducción castellana de Mígues, J.A. Meditaciones Metafísicas. Santiago de Chile: Arcis 2004.

Descartes, R., Los principios de la filosofía. Guillermo Quintás (trad.). Madrid: Alianza Editorial 1995.

Domingo Osle, R., Ortega, J. y Rodríguez-Antolín, B., Principios del derecho global. Cizur (Navarra): Aranzadi 2003.

Eisler, R., Wörterbuch der philosophischen Begriffe. Berlin: Mittler 1904. En https://www.textlog.de/3979.html (último acceso: 20-XII-2018).

Epicuro de Samos (III a.C.). Carta a Diógenes Laercio.

Ferrater Mora, J., Diccionario de filosofía abreviado. Buenos Aires: Ed. Sudamericana 1970.

Finnis, J., Grisez, G. and Boyle, J., Practical Principles, Moral Truth, and Ultimate Ends. American Journal of Jurisprudence, 32, 1987, 99-151.

Finnis, J., Scepticism, Self Refutation and the Good of Truth. En P.M.S. Hacker and J. Raz (eds.). Law, Morality and Society. Essays in Honour of H.L.A. Hart. Oxford: Clarendon Press 1977. Finnis, J., Natural Law. Aldershot: Dartmouth 1991.

Finnis, J., Ley Natural y Derechos naturales. Cristóbal S. Orrego (trad.). Buenos Aires: Ed. Abeledo-Perrot 2000.

Garrigou-Lagrange, R., El sentido común (trad. Octavio Derisi y Eugenio Melo). Buenos Aires: Desclée de Brouwer 1944.

Gibran, K., The Wisdom of Gibran: aphorisms and maxims. New York: Philosophical Library 2010.

Grisez, G., The First Principles of Practical Reasons: A Commentary on the Suma Theologiae, 1-2, Question 94, Article 2. Natural Law Forum, 44(4), 1965.

Hassemer, W., Derecho Penal Simbólico y protección de Bienes Jurídicos. E. Larrauri (trad.). En J. Bustos Ramírez (ed.). Pena y Estado. Santiago: Conosur 1995.

Husserl, E., Investigaciones Lógicas. M.G. Morente y J. Gaos (trad.). Madrid: Revista de Occidente 1976.

Jouffroy, T., De la philosophie et du sens comun. Mélanges philosophiques. París: Paulin 1833.

Kant, E., Kritik der reinen Vernunft. P. Ribas (trad). Crítica de la razón pura. Madrid: Alfaguara 2005.

Le Roy, M.E., Science et Philosophie. Revue de Métaphysique et de Morale (Suplemento de julio), 1899, 375-425.

Leibniz, G., Nouveaux essais sur l'entendement humain. París 1765. Llano, A., Gnoseología. Pamplona: Eunsa 1991. 
Maritain, J., Los grados del saber. Alfredo Frossard (trad.). Buenos Aires: Desclée de Brouwer 1947.

Maritain, J., El orden de los conceptos. Gilberte Motteau de Buedo (trad.). Buenos Aires: Club de Lectores 1967.

Maurer, A.A., Medieval Philosophy. New York: Random House 1962.

Maurer, A.A., Ockham's Razor and Chatton's Anti-Razor - Mediaeval Studies, 46, 1984, 463-475.

Millán-Puelles, A., Obras completas, t. VII. Madrid: Rialp 2015. Moore, G.E., A Defense of Common Sense. Contemporary British Philosophy, J.H. Muirhead (ed.). London: George Allen and Unwin, 1925, 192-233.

Morán y Castellanos, J., Evidencia de la naturaleza en Aristóteles. Tópicos: revista de Filosofía, 4(6), 1994, 71-87.

O'Connell, I., Self-Evidence in Finnis' Natural Law. Theory: A Reply to Sayers. Australian Journal of Legal Philosophy, 25, 2000, 111-119.

Orrego S., C., John Finnis. Controversias contemporáneas sobre la teoría de la ley natural. Acta Philosophica, 10(1), 2001, 73-92.

Orwell, G., Review of Power: A New Social Analysis by Bertrand Russell. En J. Carey (ed.) George Orwell. Essays. New York: Everyman's Library 2002.

Orwell, G., Facing Unpleasant Facts: Narrative Essays. Boston: Mariner Books 2009.

Otaduy, J., En Comentario Exegético al Código de Derecho Canónico, v. 1, $3^{\text {a }}$ ed. Pamplona: Eunsa 2002.

Polo Barrena, L., Quién es el hombre. Madrid: Rialp 1991.

Polo Barrena, L., Curso de teoría del conocimiento, vol. I. Pampona: Eunsa 2004.

Porter, J., Basic Goods and the Human Good in Recent Catholic Moral Theology, The Thomist, 57(1), 1993, 27-49.
Real Academia Española, Diccionario de la Lengua Española. Madrid 2016.

Reid, T., Essays on the Intellectual Powers of Man. Dublin: P. Byrne and J. Milliken 1790.

Riofrío Martínez-Villalba, J.C., Fines, valores y principios comunes a la propiedad intelectual, al derecho a la competencia y a otros derechos. Ius Humani. Revista De Derecho, 3, 2012a, 37-50.

Riofrío Martínez-Villalba, J.C., Las causas metafísicas como fuentes del derecho. Revista Telemática de Filosofía del Derecho, 15, 2012b, 259-308.

Riofrío Martínez-Villalba, J.C., De la pirámide de Kelsen a la pirámide invertida. REDESG Revista Direitos Emergentes na Sociedade Global, 2(2), 2013, 436-461.

Riofrío Martínez-Villalba, J.C., La selección del método en la investigación jurídica. 100 métodos posibles. Revista de Educación y Derecho, 12(2), 2015, 1-27.

Riofrío Martínez-Villalba, J.C., Síntesis de la teoría de la pirámide invertida. Ponencia del I Congreso de Filosofía del Derecho para el Mundo Latino. Alicante 2016.

Sayers, M., Knowledge as a Self-Evident Good in Finnis and Aquinas: When is the Immediately Obvious Not So Immediate. Australian Journal of Legal Philosophy, 23, 1998, 92-101. Sokolowski, R., Introduction to Phenomenology. Cambridge-New York: Cambridge University Press 2008.

Thorburn, W., The Myth of Occam's Razor. Mind, 27, 1918, 345-353.

Tomas de Aquino, Suma Teológica. París-Italia. Traducción al castellano de BAC. Suma Teológica de Santo Tomás de Aquino, $4^{\text {a }}$ ed. Madrid: BAC 2001. 